\title{
Correction to: Board Gender Diversity and Corporate Response to Cyber Risk: Evidence from Cybersecurity Related Disclosure
}

\author{
Camélia $\operatorname{Radu}^{1}{ }^{1} \cdot$ Nadia Smaili $^{1}$
}

Published online: 16 February 2021

(c) Springer Nature B.V. 2021

Correction to: Journal of Business Ethics

https://doi.org/10.1007/s10551-020-04717-9

The initial online publication incorrectly contained Supplementary Information. The original article has been corrected.

Publisher's Note Springer Nature remains neutral with regard to jurisdictional claims in published maps and institutional affiliations.

The original article can be found online at https://doi.org/10.1007/ s10551-020-04717-9.

Camélia Radu

radu.camelia@uqam.ca

Nadia Smaili

smaili.nadia@uqam.ca

1 ESG UQAM (School of Management), Université du Québec à Montréal, Montréal, Canada 